\title{
An Evaluation of the Effects of Brand Equity on Consumer Willingness to Pay Price Premium
}

\author{
Suleiman Garba Aminu \& Norzieiriani Ahmad²
}

\author{
${ }^{1}$ Department of Business Administration, Bauchi State University, Gadau, Nigeria \\ ${ }^{2}$ School of Business Management, Universiti Utara Malaysia \\ Correspondence: Department of Business Administration, Bauchi State University, Gadau, Nigeria, Email: \\ araman611@yahoo.com
}

Received: January 25, 2018

Accepted: March 2, 2018

Online Published: March 12, 2018

\begin{abstract}
The purpose of this study is to evaluate the outcome of brand equity on consumer responses by specifically investigating the effects of the overall brand equity on consumer willingness to pay premium price. The paper also empirically investigated the causal relationship among brand awareness, brand association, perceived quality, and brand loyalty as antecedents of brand equity. Using the automobile product category in Malaysia as stimuli, crosssectional survey data were collected and analyzed using partial least square structural equation modeling technique. Result showed that brand equity plays a significant role in firms by creating and developing additional value to organizations and their products. A causal relationship among the antecedents of brand equity was also established. Among the antecedents of brand equity, brand loyalty was found to be the dominant driver of overall brand equity. Moreover, the effect of brand equity on consumers' willingness to pay price premium was substantiated and found to be positive. The limitation of the paper is that the study used a single high involving product category. Future studies should use product categories with short consumption length and high purchase frequency. Findings of this study provide more insight to managers on how to manage brand equity. Outcomes of brand equity can be used to measure the performance of brand in the market. The study also provides additional clarification to the existing literature on the need for managers to develop a post-brand equity marketing strategy in order to achieve sustainable competitive advantage.
\end{abstract}

Keywords: Brands, Brand Equity, Consumer Responses, Consumer-Based Brand Equity.

\section{Introduction}

The practice of branding is as old as history itself when craftsmen and artists tried to distinguish their products from those of others by way of marking or signing (Hakala et al., 2012). With the increasing need to differentiate products, the brand has now become one of the most powerful marketing tools used by organisations. The most widely used definition of a brand is the one proffered by the American marketing association. A brand adds dimensions to products or service, differentiate it in some ways from other products or services produced to satisfy the same needs (Hakala et al,. 2012). The overall value of a brand for the company and what the brand represents in the customers' mind is considered as brand equity (Keller, 1991).

There has been a vast array of literature and studies conducted regarding brand equity, but not as much empirical studies paid attention to how consumer response is impacted by consumer based-brand equity (Buil et al., 2013). Similarly, Leone et al., (2006) argue that contemporary marketing interest has been centered on brand equity and customer equity without commensurate research attempts to reconcile the relationship between the two concepts. Still in the same vein, many researchers have observed that in international marketing, the role that brand equity plays has not been examined in detail (Pappu et al., 2006; Broyles et al., 2010). Brand equity is regarded as a key indicator of how healthy or otherwise a brand is, and observing it constantly is considered to be a necessary step in effective management of the brand (Aaker, 1991, 1992). 
Apart from measuring brand equity, the need for researchers, marketers and business practitioners to understand how consumer responses and attitude is influenced by the different dimensions of brand equity has become very vital (Hoeffler \& Keller 2003). Invariably, the value of a brand is obtained in the market through the activities of consumers. It is therefore an urgent and challenging task to study and better understand the consequences of the consumers' actions (Wang et al., 2008; Broyles et al., 2010). However, few empirical studies have been carried out to ascertain these possible outcomes (Hoeffler \& Keller 2003). Some previous studies have tried to assume that brand equity may have positive effect on consumer response (Cobb-Walgren et al., 1995). In contrast, Erdem and Swait (1998) examined that brand loyalty is a consequence rather than an antecedent of brand equity because products value proposition and consumer tastes' are closely related. Thus, lower information costs and perceived risk is seen as part of factors that bring about consumer-based brand equity (Erdem \& Swait, 1998).

Also, Yoo et al., (2000) suggested that more dynamic interactions between brand equity and consumer responses need to be studied, pointing out that though brand equity is an outcome of marketing mix effort, it can still be amplified at the same time as a product of customer value that emanates from previous brand equity. Consequently, Buil et al., (2013) conducted a study to investigate the influence of brand equity on consumer responses using data collected from Spain and the UK. Although the study found a positive influence, the study lacks generalizability because of the differing peculiarities of European cultures and other non-European countries.

Davcik et al., (2015) argued that there is a need to distinguish conflicting focuses and to blend contemporary approaches to the brand equity concept. Following an extensive research and in-depth review of literature and a taxonomical classification of extant research, Davcik et al., (2015) suggested three areas for future research avenues that will likely lead to a unifying theory of brand equity, namely: consumer and company value perspective (i.e. stakeholder value), managing marketing assets and financial performance. Therefore, this study is carried out in line with the consumer and company value perspective in order to contribute in filling the gaps identified by Davcik et al., (2015).

Considerable number of the extant literature available in the field of brand equity is largely focusing on the USA. Studies that have been carried out concurrently in different geographical settings mostly tried to observe American and Asian markets. Moreover, the studies have reported some limitations on the samples used (Yoo and Donthu, 2001, 2002; Broyles et al., 2010). Accordingly, this study was conducted in Malaysia in order to better understand and evaluate the effects of brand equity on consumer responses in other developing countries. To accomplish this, the Proton and Perodua, two leading brands in the Malaysian automobile industry were used to examine the effects of brand equity on consumer responses.

The paper begins by a general introduction followed by a review of relevant literature. A discussion of the research framework, development of hypotheses, the research design, measurement of variables, sampling and sampling techniques, data collection procedures, as well as the methods of data analysis will be discussed before presenting the results, conclusion, implication as well as the limitations of the study.

2. Literature Review and Framework

The foundation of research on contemporary consumer-based brand equity was developed by Aaker (1991) and Keller (1993). Scholars and researchers (e.g. Fetscherin, 2010; Myers, 2003) have established two major perspective of brand equity to be the financial or company-based brand equity and the consumer-based brand equity. The concept of brand equity has been defined severally by different scholars for many different reasons. Defining brand equity from a logical approach, Aaker (1991) describes it as "a set of brand assets (brand awareness, perceived quality, brand associations, brand loyalty) and liabilities linked to a brand, its name and symbol that add to or subtract from the value provided by a product or service to a firm and/or to that firm's customers". Keller (1993) on the other hand defines the concept of consumer-based brand equity as the complementary effect of brand knowledge on consumer response to the marketing activities of the brand. Keller (1993) sees brand equity in terms of brand awareness and the strength, favourability and unparalleled brand associations that consumers hold in memory. Irrespective of how it is utilized or measured however, the value of a brand, and impliedly its equity, must at the end, be derived in the marketplace from the actions and interactions of consumers (Hoeffler and Keller, 2003).+

Several other researchers (e.g. Cobb-Walgren et al., 1995; Sinha and Pappu, 1998; Yoo and Donthu, 2001, 2002; Yoo et al., 2000) have conceptualized brand equity in similar fashion to Aaker (1991) and Keller (1993) by using the term consumer-based brand equity to mean brand equity. Specifically, Yoo et al., (2000) defined brand equity as the contrasting customer choice that occurs between the branded product and an unbranded product given the equivalent level of product characteristics. Recent studies have however conceptualized brand equity as a relational market-centered asset that is built over time through the interfaces between the brands and their customers (e.g., Davcik et al. 2015; Hooley et al., 2005; Srivastava et al., 2001). The incremental satisfaction or value added to a product by its brand name has also been refered to as brand equity (Farquhar et al., 1991). Ultimately, brand equity lies in the minds of consumers and what they have gone through, learned, and felt about the brand over time (Leone 
et al., 2006) Keller (2003) posited that brand equity can be thought of as the "added value" endowed to a product in what the consumer thinks, says and how the consumer reacts. In their own adaptation of Aaker (1991) definition of brand equity, Pappu et al., (2006) defined brand equity as "the value consumers associate with a brand, as reflected in the antecedents of brand awareness, brand associations, perceived quality and brand loyalty".

There are two facets of brand equity and its precursors, namely: functional and experiential (Keller, 2002; de Chernatony and Riley, 1997). The functional aspect consists of the components of one's perception of a brand's performance and quality, including perceived performance and perceived quality (Keller 2003). The experiential facet comprise of a brand's resonance and imagery (Holbrook and Hirschman, 1982; Keller, 2003). Four main antecedents of brand equity: brand awareness, perceived quality, brand associations, and brand loyalty have been widely acknowledged by different researchers (Aaker 1991, 1996; Yoo et al., 2000; Pappu et al., 2005; Buil et al., 2013).

The outcomes of brand equity, which are the variables of primary interest and how they are affected will be examined on five factors namely; willingness to pay price premium, brand preference, purchase intention, attitudes towards brand extension, and information cost reduction. The study is conceptualized in line with Aaker (1991 p. 15) cognitive psychology approach where brand equity is seen as "a set of brand assets and liabilities linked to a brand, its name and symbol that add to or subtract from the value provided by a product or service to a firm and/or to that firm's customers". Four constructs; brand awareness, perceived quality, brand associations, and brand loyalty, that have come to be seen as the building blocks of brand equity are also adopted for this study. These brand equity antecedents have been widely examined and accepted by so many different researchers (e.g. Yoo et al., 2000; Pappu et al., 2005; Kim and Hyun, 2011; Buil et al., 2013).

Figure 1

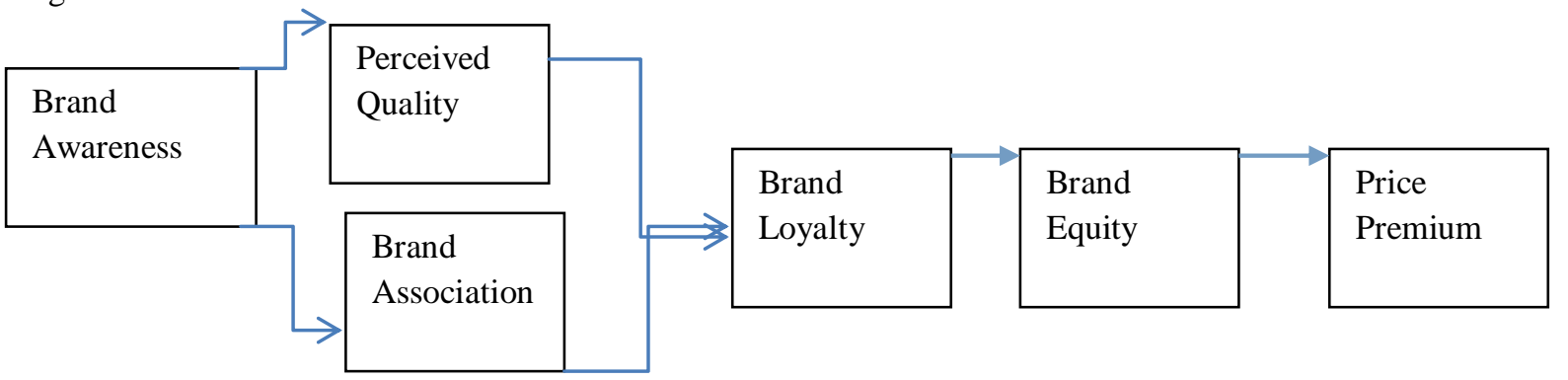

To investigate brand equity, Buil et al., (2013) observed a causative order of events among the antecedents of brand equity. Keller and Lehmann (2003) postulated this chronological process known as the customer-based brand equity hierarchy. First, brand awareness positively influence perceived quality and brand associations. Secondly, brand association has a positive and significant effect on brand loyalty. Similarly, Cob-Walgren et al., (1995) observed that brand with higher equity generated significantly greater preference and purchase intentions. Inversely, Romaniuk and Nenycz-Thiel (2013) argued that there is a positive relationship between the current tendency to pass brand association and previous behavioural loyalty. Brand awareness comprises connecting the brand to diverse associations in memory (Keller, 2003). Thus, consumers brand association is a function of brand awareness (Aaker, 1991).

$\mathrm{H}_{1:}$ Brand awareness has a positive impact on perceived quality.

$\mathrm{H}_{2}$ : Brand awareness has a positive impact on brand associations

Aaker (1991) defines brand associations as "anything linked in memory to a brand" and brand image as "a set of [brand] associations, usually in some meaningful way" (p. 109). Complex and connected to one another, brand associations consists of multiple ideas, instances, happenings, and facts that establish a solid network of brand knowledge. A more strong association occurs when there are several experiences and exposures instead of few instances (Aaker 1991; Alba and Hutchinson 1987). Brand associations and brand equity are positively related because they can be an indication of quality and promise and they help a buyer consider the brand at the point of purchase resulting in a favourable behaviour for the brand (Yoo et al., 2000).

Hoeffler and Keller (2003) found that strong brands attract preferential evaluations of features and higher perceived quality as well as generally high overall preference. Perceived quality is also another preceding construct of brand loyalty (Keller and Lehmann, 2003). Thus we hypothesize that:

H3: Perceived quality has a positive impact on brand loyalty.

H4: Brand association has a positive impact on brand loyalty.

H5: Brand loyalty has a positive impact on overall brand equity. 
The amount a consumer is ready to pay for a particular brand of product in relation to a rival brand with similar value proposition is a reflection of the consumer's willingness to pay price premium (Persson, 2010). A review of the literature shows that brand equity has a noble impact on consumers' willingness to pay a price premium (Netemeyer et al., 2004; Buil et al., 2013). Consumers are less sensitive to price hikes in brands with strong equity and are ready to pay a higher price because of the perceived superior value in the brand that they believe is nonexistent in other alternative brands (Hoeffler and Keller, 2003; Keller and Lehmann, 2003). Therefore, it is hypothesize that:

H6: Overall brand equity has a positive impact on consumers' willingness to pay price premiums.

3.Research Methodology

Essentially, therefore, this study tests hypotheses by investigating the causal relationship among the identified variables in order to explain the variance in the dependent variable and its possible outcomes. In explaining nature of certain relationships, hypothesis testing is usually used (Cavana et al., 2001). To accomplish this, the Proton and Perodua, two leading brands in the Malaysian automobile industry were used to examine the effects of brand equity on consumer responses. Automobile was chosen because it is a high involving durable good that consumers normally try to make informed decision about a brand based on prior knowledge and information sought. According to the Malaysian Automobile Association, Proton and Perodua have a combined market share of 50\%. Respondents that have known and experienced products well are likely to provide reliable and valid responses to the questionnaire (Yoo et al., 2000). Hence, the two leading brands were chosen. The questionnaire was divided into two, one for each brand. Respondents were randomly given questionnaire to respond on either of the brand. This is in line with previous procedures used by researchers (e.g. Pappu et al., 2005).

3.1 Sample and Procedure

Data for this study were collected through a self-administered survey using questionnaires distributed among post graduate students at the Universiti Utara Malaysia (UUM). A total of at least 400 questionnaires were distributed by the researcher. This study adapts the survey procedures employed by Pappu et al., (2005) and Buil et al., (2013). Postgraduate students were selected because the stimuli or product category used to examine the impact of brand equity on consumer response is the automobile. Postgraduate students are also familiar with the brands, hence the study's decision to use them as sample. This study adopts a non-probability sampling method in selecting the sample size of 384 from the total population. In addition, the convenience non-probability sampling procedure was used in collecting data in three postgraduate schools of UUM.

The data collected were appropriately analysed to ascertain whether or not the hypotheses formulated have been supported. It is also to determine whether the objectives of the study have been substantiated. Partial Least Square Structural Equation Modelling (PLS-SEM) was used to analyse the data because of its predictive technique (Sanchez-Franco, 2006).

\subsection{Measurement}

Well entrenched scales were used to measure the variables included in the model. The study used a seven point interval scale where 1 is strongly agree and 7 is strongly disagree as it is one of the recommended widely used scales (Zikmund et al., 2013 p. 316).

Brand awareness was measured using five items that assess recall, recognition and familiarity with the brand (Yoo et al., 2000; Buil et al., 2013). For perceived quality, four items to measure the construct were adopted from previous works (Pappu et al. 2005; Buil et al., 2013). In measuring brand equity antecedents, some latent construct such as brand image, can be drawn-out to clarify the underlying construct in detail (Yoo and Donthu, 2001). Therefore, three types of associations extensively used in past literature were incorporated: organisational association, brand personality and perceived value, (Aaker, 1996; Pappu et al., 2005; Buil et al., 2013). Lastly, the scale used by Yoo et

al. (2000) was used to operationalize brand loyalty.
Similarly, overall brand equity measurement was also adopted from the works of Yoo et al., (2000). Finally, to measure the willingness to pay price premium, three items were adopted from previous studies by Netemeyer et al., (2004) and Buil et al., (2013).

4. Analysis and Results

The assessment of the research model was carried out in two stages, i.e. the structural model and the measurement model as per Hair et al., (2013). A total of 400 questionnaires were distributed but only 243 were returned representing $60.75 \%$ response rate. All the items in the questionnaire were labeled with a code as follows; brand awareness items were labeled AW1-AW5, perceived quality PQ1-PQ4, brand association ASS1-ASS9, brand loyalty LO1-LO3, overall brand equity OBE1-OBE, and price premium PPR1-PP

4.1 Measurement Model

Discriminate and convergent validity, composite reliability, and average variance extracted (AVE) were used to assess the measurement model. An AVE with a value of at least 0.50 indicates that, on average, the construct 
explains more than half of the variance of its indicators. Table I indicates that all the constructs of the measurement model are above the minimum 0.50 value required to explain the variance. All the items had a Cronbach's alpha of more than 0.70 . Furthermore, the composite reliability results which show the different outer loadings of the indicator constructs had satisfactory values of 0.90 and above (Hair et al., 2013).

The Fornell-Larcker criterion was used to assess discriminant validity in this study. The criterion suggests a

Table 1:Convergent validity

\begin{tabular}{clllll}
\hline & AVE & Composite & \multicolumn{4}{c}{ Cronbach' } \\
& Reliability & \multicolumn{3}{c}{ R Square s Alpha } & Redundancy \\
\hline Brand Awareness & 0.666 & 0.909 & 0 & 0.875 & 0 \\
Brand Ass & 0.661 & 0.946 & 0.401 & 0.935 & 0.263 \\
Brand Loyalty & 0.857 & 0.947 & 0.534 & 0.917 & 0.371 \\
Overall Brand equity & 0.838 & 0.954 & 0.631 & 0.935 & 0.528 \\
Perceived quality & 0.840 & 0.954 & 0.300 & 0.936 & 0.252 \\
Price premium & 0.782 & 0.914 & 0.527 & 0.855 & 0.412 \\
\hline
\end{tabular}

comparison between the square roots of the AVE values with the latent variable correlation. Precisely, the square root of each construct's AVE should be larger than its highest correlation with any other construct. Moreover, the discriminant validity was also assessed by the value of latent variable indicator loadings and cross-loading, where the loading for a particular indicator must be higher in its own construct than its shared loading with other constructs. Table II indicates that 0.795 is the highest correlation value between overall brand equity and brand loyalty. On the other hand, the values of square root of average variance extracted for all the constructs (the bold diagonal) are all above the correlation among other constructs (the off- diagonal). The lowest value of the square root of AVE is 0.813 for brand association, which is above the value of correlations of any constructs in the model.

Table2: Discriminant validity

\begin{tabular}{cllllll}
\hline & $\begin{array}{l}\text { Brand } \\
\text { Awareness }\end{array}$ & $\begin{array}{l}\text { Brand } \\
\text { association }\end{array}$ & $\begin{array}{l}\text { Brand } \\
\text { loyalty }\end{array}$ & $\begin{array}{l}\text { Overall } \\
\text { equity }\end{array}$ & $\begin{array}{c}\text { brand Perceived } \\
\text { quality }\end{array}$ & $\begin{array}{c}\text { Price } \\
\text { premium }\end{array}$ \\
\hline Brand awareness & 0.816 & & & & & \\
Brand association & 0.633 & 0.813 & & & & \\
Brand loyalty & 0.461 & 0.705 & 0.926 & & & \\
Overall Brand equity & 0.471 & 0.696 & 0.795 & 0.915 & & \\
Perceived quality & 0.548 & 0.795 & 0.677 & 0.671 & 0.916 & \\
Price premium & 0.358 & 0.536 & 0.744 & 0.726 & 0.546 & 0.884 \\
\hline
\end{tabular}

\subsection{Structural Model}

The structural model on the other hand was assessed using coefficient of determination (R2) and hypotheses were tested to determine path relationship using bootstrapping procedure as suggested by Hair et al., (2013). In order to obtain the statistical t-values and the standard error, the PLS bootstrapping resampling was conducted as recommended (Hair et al 2013). Prior to that, PLS standard algorithm was also calculated during measurement model assessment, thus the path coefficients and the directionality of the relationships was obtained. The p-value was calculated at 95 per cent confidence level, as it is acceptable in social science research (Zikmund et al., 2013).

Table 3: Result of hypotheses testing

\begin{tabular}{|c|c|c|c|c|c|c|}
\hline Hypotheses & & Beta & $\begin{array}{l}\text { Standard } \\
\text { Error }\end{array}$ & T-stat & P-Value & Decision \\
\hline & awareness & & & & & \\
\hline H1 & Association & 0.633 & 0.071 & 8.961 & 0.00 & Supported \\
\hline $\mathrm{H} 2$ & Brand awareness -> Perceived quality & 0.548 & 0.076 & 7.257 & 0.00 & Supported \\
\hline H3 & Brand association $->$ Brand loyalty & 0.453 & 0.135 & 3.362 & 0.00 & Supported \\
\hline H4 & $\begin{array}{l}\text { Brand Loyalty } \rightarrow \text { Overall Brand } \\
\text { equity }\end{array}$ & 0.795 & 0.042 & 19.138 & 0.00 & Supported \\
\hline
\end{tabular}




\begin{tabular}{llllllll} 
H5 & Overall Brand equity & premium & Price & & & & \\
H6 & & 0.726 & 0.053 & 13.601 & 0.00 & Supported \\
H6 & Perceived quality & -> Brand Loyalty & 0.317 & 0.130 & 2.439 & 0.01 & Supported \\
\hline
\end{tabular}

5. Discussion and Implication

Result of this study showed that in the build up to brand equity, there is a causal relationship among the antecedents. This finding is in agreement with previous studies (Buil et al., 2013; Torres et al., 2015). Brand awareness positively influence perceived quality and brand association, in the same way perceived quality and brand association influence brand loyalty. This hierarchy of effects has also been established in the literature as an important activity in understanding brand equity (Cobb-Walgren et al., 1995; Keller and Lehman 2003. When consumers gain awareness of a particular brand, they then develop a positive or negative association of the brand which is tied to their knowledge of the brands' performance. This finding has been corroborated by similar study conducted in Malaysia by Sasmita\&Suki (2015). Although this finding is in agreement with a similar study conducted in Europe where perceived quality positively influence brand equity (Buil et al., 2013), Torres et al., (2015) nevertheless argued that, the influence of perceived quality on brand equity is mediated by brand loyalty. It further points out that perception of quality is a necessary driver of overall brand equity among Malaysian consumers. Similarly, and unsurprisingly, brand loyalty has a very strong positive influence on overall brand equity which is in conformity with previous research (Yoo et al., 2000; Bravo et al., 2007).

This study also sought to provide empirical evidence on consumers' willingness to pay price premium for brands with favourable and strong equity. The result of the study indicates that consumers' are willing to part with more money to purchase a specific brand which is a very vital outcome of brand equity.

5.1 Implication of the Study

Building brand equity theory requires a cross-contextual framework that cuts across different types of brand as well as different geographic locations (Davcik et al., 2015). The research implication of this study is that it contributes towards a more holistic and inclusive brand equity theory building by using a model that incorporates four antecedents of brand equity as well as an outcome of brand equity. Moreover, most of the brand equity theory building studies conducted were in the developed countries of North America and Europe. This study comes from a different geographical perspective which is a fundamental requirement for building a unified accepted theory of brand equity.

From a managerial viewpoint, this study found out a causal relationship among brand equity antecedents which mean that managers should strive to create strong brand awareness first as a precondition to building brand image (brand association) and perceived quality. At this stage, marketing efforts that will entrench top of mind awareness and stimulate brand recall and recognition should form part of the management's priority. For a brand to be successful, it must first be part of consideration set in consumers' memory (Hakala et al., 2012). Perceived quality and brand association breeds brand loyalty, which has been seen to have the most influence on brand equity. As per the result of this study, and in Malaysian context, brand association plays a nobler role in building brand equity than perceived quality. Therefore, managers should ensure consumers brand encounter convey favourable brand attributes, benefits, and overall favourable brand attitude. Additionally, as pointed out earlier, because brand loyalty is the dominant influencer of overall brand equity, marketing managers should direct their energy towards marketing activities that will build brand loyalty.

Development of a multi-level research framework has been advocated in the literature (Davcik et al., 2015). This study also integrates a post-brand equity model that investigates the outcomes of brand equity. The findings of this study will help managers in designing a long term brand marketing strategy that will prevent switching tendencies by developing a heterogeneous brand through extension. Moreover, managers can better manage price wars with a brand with positive brand equity. Brand managers are constantly under intense pressure to justify to management how brand portfolios are adding value to the firm. This study shows that positive brand equity leads to the customers' willingness to pay a premium price.

\subsection{Conclusion, Limitations and Future Research Direction}

This study like many other studies in the social sciences is not devoid of limitations that can provide an avenue for future research. First, the study used only one product category which is the automobile, a high involving product with a relatively low purchase frequency. Other products category that are less involving with relatively shorter consumption length can be used in future studies. Secondly, the study was conducted in Malaysia only, which means generalization of findings has to be done with caution, owing to the cultural peculiarities of the country. For example, consumer perception of quality may rank higher in the build up to brand equity in some countries, contrary to the findings of this study. There is also the need to study other possible outcomes of brand equity which have not been within the scope of this study. Similarly, Chritodoulides et al., (2015) observed that some brand equity 
dimension may be inconsistent across countries. Lastly, the study was conducted from the perspective of the consumer. Future studies can look at it from the company and financial perspective with a view to building unified brand equity theory.

Brand equity can be a veritable tool for organizations to achieve sustainable competitive advantage. The four antecedents of brand equity appear to have been firmly rooted in the literature as there has been a near consensus among scholars and researchers alike. This has brought about a paradigm shift in research away from building brand equity to managing brand equity by measuring its outcomes. This is occasioned by the need for marketers to better understand how consumers respond to brand with strong and positive equities. As evident in this study, consumers' willingness to pay price premium is positively hinged on brand equity. This study was conducted using a model capable of achieving objectivity and parsimony required in a scientific research.

References

Aaker, D. A. (1992).The value of brand equity.Journal of business strategy, 13(4), 27-32.

Aaker, D.A. (1991) Managing brand equity. capitalizing on the value of brand name, The Free Press, New York, $N Y$

Aaker, D.A. (1996). "Measuring brand equity across products and markets", California Management Review, 38(3), 102-20.

Ailawadi, K., Lehmann, D. \&Neslin, S. (2003). "Revenue premium as an outcome measure of brand equity", Journal of Marketing, 67(4), 1-17

Alba, J. W., \& Hutchinson, J. W. (1987).Dimensions of consumer expertise.Journal of Consumer Research, 411454.

Bravo, R., Fraj, E. \& Martinez, E. (2007). "Family as a source of consumer-based brand equity", Journal of Product and Brand Management, 16(3), 188-99.

Broyles, S.A., Leingpibul, T., Ross, R.H. \& Foster, B.M. (2010). "Brand equity's antecedent/consequence relationships in cross-cultural settings", Journal of Product and Brand Management, 19(3), 159-69

Buil, I., Martínez, E., \& de Chernatony, L. (2013).The influence of brand equity on consumer responses.Journal of Consumer Marketing, 30(1), 62-74.

Cavana, R. Y., Delahaye, B. L., \& Sekaran, U. (2001). Applied business research: Qualitative and quantitative methods.John Wiley \& Sons Australia.

Cobb-Walgren, C., Ruble, C.A. \& Donthu, N. (1995). "Brand Equity, Brand Preference and Purchase Intent", Journal of Advertising, 24(3), 25-40.

Davcik, N. S., Vinhas da Silva, R., \& Hair, J. F. (2015). Towards a Unified Theory of Brand Equity: Conceptualizations, Taxonomy and Avenues or Future Research. Journal of Product \& Brand Management, 24(1), 3-17.

De Chernatony, L., \& Riley, F. D. O. (1997). The chasm between managers' and consumers' views of brands: the experts' perspectives. Journal of Strategic Marketing, 5(2), 89-104.

Erdem, T., \& Swait, J. (1998). Brand Equity as a Signaling Phenomenon. Journal of Consumer Psychology, 7(2), 131-157.

Erdem, T., Swait, J., \& Valenzuela, A. (2006). Brands as signals: A cross-country validation study. Journal of Marketing, 70(1), 34-49.

Farquhar, P. H., Han, J. Y., \& Ijiri, Y. (1991).Recognizing and Measuring Brand Assets.Report/Marketing Science Institute (USA).

Farquhar, P. H., Han, J. Y., Herr, P. M., \& Ijiri, Y. (1992). Strategies for leveraging master brands: How to bypass the risks of direct extensions. Marketing Research, 4(3), 32.

Fetscherin, M. (2010). The determinants and measurement of a country brand: the country brand strength index. International Marketing Review,27(4), 466-479.

Hair Jr, J. F., Hult, G. T. M., Ringle, C., \&Sarstedt, M. (2013). A primer on partial least squares structural equation modeling (PLS-SEM). Sage Publications.

Hakala, U., Svensson, J., \& Vincze, Z. (2012). Consumer-Based Brand Equity and Top-of-Mind Awareness: a Cross-Country Analysis. Journal of Product \& Brand Management, 21(6), 439-451.

Hoeffler, S. \& Keller, K.K. (2003).“The Marketing Advantages of Strong Brands", Brand Management, 10(6), 42145.

Holbrook, M. B., \& Hirschman, E. C. (1982). The experiential aspects of consumption: Consumer fantasies, feelings, and fun. Journal of consumer research, 132-140.

Hooley, G. J., Greenley, G. E., Cadogan, J. W., \&Fahy, J. (2005). The Performance Impact of Marketing Resources.Journal of Business Research, 58(1), 18-27. 
Keller, K. L. (1993). Conceptualizing, Measuring, and Managing Customer-Based Brand Equity. The Journal of Marketing, 1-22.

Keller, K.L. \& Lehmann, D.R. (2003). “How Do Brands Create Value?”,Marketing Management, May/June, Pp. 27-31

Keller, K.L. (2003). Strategic Brand Management: Building, Measuring, and Managing Brand Equity, (2nd Ed)., Prentice Hall, New York, NY.

Kim, J. H., \& Hyun, Y. J. (2011).A model to investigate the influence of marketing-mix efforts and corporate image on brand equity in the IT software sector. Industrial Marketing Management, 40(3), 424-438.

Kotler, P. (2009). Marketing management: A south Asian perspective. Pearson Education India.

Krejcie, R. V., \& Morgan, D. W. (1970). Determining sample size for research activities. Educpsychol meas.

Laroche, M., Kim, C., \& Zhou, L. (1996). Brand Familiarity and Confidence as Determinants of Purchase Intention: An Empirical Test in a Multiple Brand Context. Journal of Business Research, 37(2), 115-120.

Leone, R.P., Rao, V.R., Keller, K.L., Luo, A.M., Mcalister, L. \& Srivastava, R. (2006). "Linking Brand Equity to Customer Equity", Journal of Service Research, 9(2), 125-138.

Martinez, E. \& Pina, J.M. (2009). "Modeling the Brand Extensions' Influence on Brand Image”, Journal of Business Research, 62 (1), 50-60.

Meyvis, T., \& Janiszewski, C. (2004). When are broader brands stronger brands? An accessibility perspective on the success of brand extensions.Journal of Consumer Research, 31(2), 346-357.

Milberg, S.J. \& Sinn, F. (2008)."Vulnerability of Global Brands to Negative Feedback Effects”, Journal of Business Research, 61, 684-90.

Myers, C. A. (2003). Managing brand equity: a look at the impact of attributes. Journal of Product \& Brand Management, 12(1), 39-51.

Mourali, M., Laroche, M., \& Pons, F. (2005).Antecedents of Consumer Relative Preference for Interpersonal Information Sources in Pre-Purchase Search. Journal of Consumer Behaviour, 4(5), 307-318.

Netemeyer, R., Krishnan, B., Pullig, C., Wang, G., Yagci, M., Dean, D., Ricks, J. \& Wirth, F. (2004). "Developing and Validating Measures of Facets of Customer-Based Brand Equity”, Journal of Business Research, 57, 209-24.

Pappu, R., Quester, P.G. \& Cooksey, R.W. (2005). "Consumer-Based Brand Equity: Improving the Measurement. Empirical Evidence", Journal of Product and Brand Management, 14(3), 143-54.

Pappu, R., Quester, P.G. \& Cooksey, R.W. (2006). "Consumer-Based Brand Equity and Country-of-Origin Relationships", European Journal of Marketing, 40(5/6), 696-717.

Park, C. S., \& Srinivasan, V. (1994).A Survey-Based Method for Measuring and Understanding Brand Equity and its Extendibility.Journal of Marketing Research, 271-288.

Persson, N. (2010). An exploratory investigation of the elements of B2B brand image and its relationship to price premium. Industrial Marketing Management, 39(8), 1269-1277.

Romaniuk, J., \& Nenycz-Thiel, M. (2013). Behavioural brand loyalty and consumer brand associations. Journal of Business Research, 66(1), 67-72.

Sanchez-Franco, M. J. (2006). Exploring the influence of gender on the web usage via partial least squares. Behaviour \& Information Technology,25(1), 19-36.

Sasmita, J., \&Suki, N.M. (2015).Young consumers' insight on brand equity.International journal of retail \& distribution management, 44(3), 276-292

Shugan, S. M. (1980). The cost of thinking. Journal of consumer Research, 99-111.

Sinha, A., \& Pappu, R. (1998).Parcelling of the Sub-Components Of Consumer-Based Brand Equity Using Factorial Survey: An Empirical Investigation in The New Zealand Consumer Electronics Sector. In Proceedings, Australia New Zealand Marketing Academy Conference (ANZMAC), University Of Otago, Dunedin,(December) (Pp. 156-57).

Srivastava, R. K., Fahey, L., \& Christensen, H. K. (2001). The Resource-Based View and Marketing: The Role of Market-Based Assets in Gaining Competitive Advantage. Journal of Management, 27(6), 777-802.

Torres, P. M., Augusto, M. G., \&Lisboa, J. V. (2015).Determining the causal relationships that affect consumerbased brand equity: The mediating effect of brand loyalty. Marketing Intelligence \& Planning, 33(6), 944956.

Wang, H., Wei, Y. and Yu, C. (2008). "Global brand equity model: combining customer-based with productmarket outcomes approaches", Journal of Product and Brand Management, 15(5), 305-16.

Yasin, N.M., Noor, M.N. \& Mohamad, O. (2007). "Does Image of Country-of-Origin Matter to Brand Equity?",Journal of Product and Brand Management, 16 (1), 38-48. 
Yoo, B. \& Donthu, N. (2001).“Developing and Validating a Multidimensional Consumer-Based Brand Equity Scale", Journal of Business Research, 52, 1-14.

Yoo, B., Donthu, N. \& Lee, S. (2000). "An Examination of Selected Marketing Mix Elements and Brand Equity", Journal of the Academy of Marketing Science, 28(2), 195-211.

Zikmund, W., Babin, B., Carr, J., \& Griffin, M. (2013). Business research methods. Cengage Learning.

\section{Copyrights}

Copyright for this article is retained by the author(s), with first publication rights granted to the journal.

This is an open-access article distributed under the terms and conditions of the Creative Commons Attribution license (http://creativecommons.org/licenses/by/4.0/) 